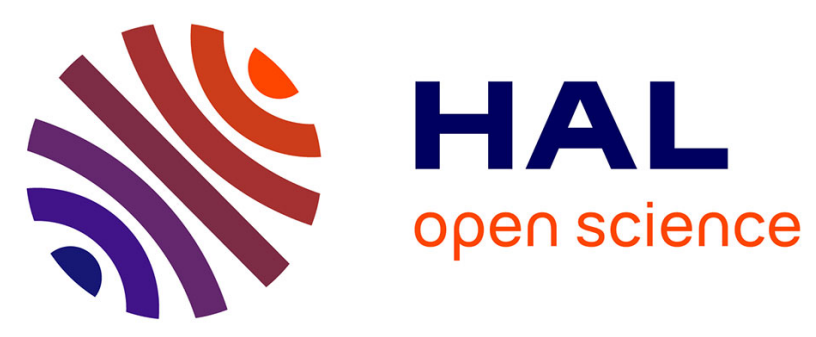

\title{
Abietane diterpenes from the cones of Abies numidica de Lannoy ex Carrière (Pinaceae) and in vitro evaluation of their antimicrobial properties
}

Maya Belhadj Mostefa, Amin Abedini, Laurence Voutquenne-Nazabadioko, Sophie C. Gangloff, Ahmed Kabouche, Zahia Kabouche

\section{To cite this version:}

Maya Belhadj Mostefa, Amin Abedini, Laurence Voutquenne-Nazabadioko, Sophie C. Gangloff, Ahmed Kabouche, et al.. Abietane diterpenes from the cones of Abies numidica de Lannoy ex Carrière (Pinaceae) and in vitro evaluation of their antimicrobial properties. Natural Product Research, 2016, 31 (5), pp.568-571. 10.1080/14786419.2016.1190723 . hal-01996329

\section{HAL Id: hal-01996329 \\ https://hal.univ-reims.fr/hal-01996329}

Submitted on 4 Oct 2021

HAL is a multi-disciplinary open access archive for the deposit and dissemination of scientific research documents, whether they are published or not. The documents may come from teaching and research institutions in France or abroad, or from public or private research centers.
L'archive ouverte pluridisciplinaire HAL, est destinée au dépôt et à la diffusion de documents scientifiques de niveau recherche, publiés ou non, émanant des établissements d'enseignement et de recherche français ou étrangers, des laboratoires publics ou privés. 


\section{Abietane diterpenes from the cones of Abies numidica de Lannoy ex Carrière (Pinaceae) and in vitro evaluation of their antimicrobial properties}

Maya Belhadj Mostefa ${ }^{a}$, Amin Abedini ${ }^{b}$, Laurence Voutquenne-Nazabadioko ${ }^{\mathrm{b}}$, Sophie C. Gangloff ${ }^{c}$, Ahmed Kabouche ${ }^{\mathrm{a}}$ and Zahia Kabouche ${ }^{\mathrm{a} *}$

${ }^{a}$ Université des frères Mentouri-Constantine, Département de chimie, Laboratoire d'Obtention de Substances Thérapeutiques (L.O.S.T), 25000 Constantine, Algeria.

${ }^{\mathrm{b}}$ Groupe Isolement et Structure, Institut de Chimie Moléculaire de Reims (ICMR), CNRS UMR 7312, Moulin de la Housse, BP 1039, 51687 Reims, France.

${ }^{c}$ Laboratoire de Microbiologie, EA 4691, UFR de Pharmacie, 1 Rue du Maréchal Juin, 51096 Reims Cedex, France.

*Corresponding Authors

Pr zahia Kabouche, Université Mentouri-Constantine

E-mail : zahiakabouche@gmail.com Phone : 


\begin{abstract}
Eight known abietane diterpenes (1-8) were isolated for the first time from Abies numidica cones (Pinaceae). The structures of all compounds were established by means of 1D and 2D NMR, and UV spectral analyses. The hydromethanolic extract of A. numidica cones was tested for its antimicrobial activity against 17 Gram-positive and Gram-negative bacteria and against 5 yeasts by the use of liquid and solid medium and bioautography methods. The best antimicrobial activity was found against Gram-positive bacteria (MIC $\leq 0.3 \mathrm{mg} / \mathrm{mL}$ ) Bacillus subtilis, Enterococcus faecalis ATCC 1034, Staphylococcus aureus 8325.4, Staphylococcus aureus CIP 53.154, Micrococcus luteus and Listeria innocua and against Candida yeasts. The determination of MIC's of isolated products showed a high activity of compounds $\mathbf{4}$ and $\mathbf{6}$ against S. aureus, L. innocua $(\mathrm{MIC}=62.5 \mu \mathrm{g} / \mathrm{mL})$ and E. faecalis $(\mathrm{MIC}=125 \mu \mathrm{g} / \mathrm{mL})$.
\end{abstract}

Keywords: Abies numidica; Pinaceae; abietane diterpenes; antimicrobial activity; solid medium; liquid medium; bioautography 


\section{Introduction}

Abies is an important genus of the Pinaceae family. About 50 species are distributed in North Africa, Europe, North and Middle America and highlands of Asia (Zheng et al. 1978). Triterpenoids, steroids, flavonoids, phenols, fatty acids, and lignans have been previously reported (Yang et al. 2008). Abies species have exhibited several activities, including antitumour (Kim et al. 2004), anti-inflammatory, antihypertensive, anti-ulcerogenic (Singh et al. 2000), antibacterial (Vishnoi et al. 2007), antifungal (Aoyama et al. 1992), antitussive (Nayak et al. 2003), and central nervous system activities (Nayak et al. 2004). The cones of Abies numidica de Lannoy ex Carrière were used in folk medicine against cold, indigestion, stomachache, pulmonary, vascular and venereal diseases (Fujita et al. 1995). We report here, the phytochemical composition and the in vivo antimicrobial activity of the cones of $A$. numidica.

\section{Result and discussion}

Chromatography of the hydromethanolic extract of the cones of A. numidica afforded eight

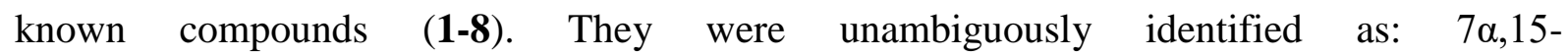
dihydroxydehydroabietic acid (1) (Prinz et al. 2002),13ß-hydroxy-7oxo-8(14)-abieten-18-oic acid (2) (Ohtsu et al. 2000), 15-hydroxy-7-oxo-dehydroabietic acid (3) (Matsumoto et al. 1988), 7a-hydroxydehydroabietic acid (4) (Miguel Del Corral et al. 1994), 7oxodehydroabietinol (5) (Tanaka et al. 1997), 7 $\alpha$-hydroxy-15-methoxy-dehydroabietic acid (6) (Xian-Wen et al. 2010), 4-hydroxy-18-nor-8,11,13-abietatrien-7-one (7) (Lee et al. 1995) and 15-hydroxydehydroabietic acid (8) (Cheung et al. 1993) (figure 1) by comparison of their spectroscopic data with literature values.

The antimicrobial potential of the hydromethanolic extract of $A$. numidica cones was evaluated against 22 microorganisms including Gram-positive and Gram-negative bacteria as well as fungi by the MIC's evaluation in solid and liquid medium (Abedini et al. 2014; Acebey-Castellon et al. 2011). In solid media, the hydromethanolic extract was active at different degrees against 12 bacterial strains, particularly Gram-positive bacteria (Table 1). No antimicrobial activity was found against the Gram-negative bacteria strains, Escherichia coli CIP 54.127, Enterobacter cloacae, Salmonella enterica, Klebsiella pneumoniae and Providencia stuartii. The best antibacterial activity was obtained against six microorganisms namely Bacillus subtilis, Enterococcus faecalis ATCC 1034, Staphylococcus aureus 8325-4, Staphylococcus aureus CIP 53.154, Micrococcus luteus and Listeria innocua with MIC's values on agar below $\leq 0.3 \mathrm{mg} / \mathrm{mL}$. The exact MIC values, in the liquid media, against these 
six bacterial strains, reveal that the hydromethanolic extract have a strong activity against Bacillus subtilis (MIC $=62.5 \mu \mathrm{g} / \mathrm{mL}$ ) and a good antimicrobial activity against $E$. faecalis, $S$. aureus 8325-4, S. aureus CIP 53.154, M. luteus and L. innocua (MIC $\leq 250 \mu \mathrm{g} / \mathrm{mL}$ ) .This activity is very interesting for a crude extract (Toyang et al. 2012). To identify the compounds having an antibacterial activity in this extract, a bioautography assay (Abedini et al. 2013; Acebey-Castellon et al. 2011) was performed with the pure compounds (1-8) against Staphylococcus aureus CIP 53.154, one of the most sensitive microorganisms. Bioautography showed good to moderate activity for the five dehydroabietic acid derivatives $(\mathbf{1}, \mathbf{3}, \mathbf{4}, \mathbf{6}, \mathbf{8})$ and low activity for compound 7 (Table 2). Therefore, these compounds were tested separately in liquid medium against S. aureus CIP53-154, L. innocua and E. faecalis ATCC 1034 (Table 2). Like bioautography, 4 and $\mathbf{6}$ showed the greatest activity against S. aureus and L. innocua (MIC=62.5 $\mu \mathrm{g} / \mathrm{ml}$ ) which is very close to MICs of antibiotics. They were less active against $E$. faecalis $(\mathrm{MIC}=125 \mu \mathrm{g} / \mathrm{mL})$. Compound 1 showed a good activity against $L$. innocua $(\mathrm{MIC}=62.5 \mu \mathrm{g} / \mathrm{mL}$ ) and a moderate activity against $S$. aureus and $E$. faecalis $(\mathrm{MIC}=$ $125 \mu \mathrm{g} / \mathrm{mL}$ ). Compounds $\mathbf{3}, \mathbf{7}$ and $\mathbf{8}$ exhibited a moderate activity with MICs ranging between 125 and $500 \mu \mathrm{g} / \mathrm{mL}$. These results suggest that the presence of hydroxyl group in $7 \alpha$ position $(1,4,6)$ may increase the antimicrobial activity of dehydroabietic acid derivatives compare to a ketone group $(\mathbf{2}, \mathbf{3}, \mathbf{5}, \mathbf{7})$ as observed by Gouiric et al (2004). On the other hand, a carboxyl group in $\mathrm{C}-18$ position in dehydroabietic acid derivatives seems to be more selective to the antibacterial activity.

The in vitro antifungal activity of the hydromethanolic extract was also tested against five yeasts and was active at $5 \mathrm{mg} / \mathrm{mL}$ MIC's value against Candida glabrata and at $10 \mathrm{mg} / \mathrm{mL}$ MIC's value against Candida tropicalis, C. kefyr and C. albicans (Table 1).

\section{Conclusions}

Eight abietane diterpenes (1-8) were isolated for the first time from the cones of Abies numidica. The hydromethanolic extract was screened for their antibacterial and antifungal activities and demonstrated antibacterial activity against Bacillus subtilis, Enterococcus faecalis, Staphylococcus aureus 8325-4, Staphylococcus aureus CIP 53.154, Micrococcus luteus and Listeria innocua with MIC's ranging from 62.5 to $250 \mu \mathrm{g} / \mathrm{mL}$.

Compounds 4 and 6 showed strong activity against S. aureus 8325-4 and L. innocua $(\mathrm{MIC}=62.5 \mu \mathrm{g} / \mathrm{mL})$, and compounds $\mathbf{1}, \mathbf{3}, \mathbf{7}$ and $\mathbf{8}$ a good antimicrobial activity. This work reveals that this plant can be used as potent sources of new antimicrobial agents against bacteria which are increasingly becoming resistant to traditional antibiotics. 


\section{Acknowledgment}

The authors are grateful to ATRSS and DGRSDT (MESRS, Algeria), to university Mentouri Constantine-Algeria and to Groupe Isolement et Structure of the Institut de Chimie Moléculaire de Reims (ICMR), France for providing their financial support and facilities during the study. We also acknowledge Janick Madoux (Laboratory of Bacteriology, CHU Reims) for accessing to multiple inoculators material, Pr Jerome Depaquit (Laboratory of parasitology-Mycology) for providing yeasts and Chantal Grimplet for technical support.

\section{Supplementary material}

The experimental part of this article can be accessed on line at ....

\section{References}

Abedini A, Roumy V, Mahieux S, Biabiany M, Standaert-Vitse A, Rivière C, Sahpaz S, Bailleul F, Neut C, Hennebelle T. 2013. Rosmarinic acid and its methyl ester as antimicrobial components of the hydromethanolic extract of Hyptis atrorubens Poit. (Lamiaceae). Evid Based Complement Alternat Med. 604536.

Abedini A, Roumy V, Mahieux S, Gohari A, Farimani MM, Rivière C, Samaillie J, Sahpaz S, Bailleul F, Neut C, Hennebelle T. 2014. Antimicrobial activity of selected Iranian medicinal plants against a broad spectrum of pathogenic and drug multiresistant microorganisms. Lett Appl Microbiol. 59(4): 412-421.

Acebey-Castellon IL, Voutquenne-Nazabadioko L, Doan TMH, Roseau N, Boutaghane N, Muhammad D, Le Magrex-Debar E, Gangloff S, Litaudon M, Sevenet T, Hung NV, Lavaud C. 2011. Triterpenoids saponins from Symplocos lancifolia. J Nat Prod. 74:163168.

Aoyama M, Doi S.1992. Antifungal activities of wood extractives of todomatsu, Abies sachalinensis Masters against pathogenic fungi causing turfgrass diseases. Mokuzai Gakkaishi. 38:101-105.

Cheung HTA, Miyase T, Lenguyen MP, Smal MA. 1993. Further neutral acidic constituents of Pinus massoniaca resin. Tetrahedron. 9:7903-7915.

Fujita T, Sezik E, Tabata M, Yesilada E, Honda G, Takeda Y, Tanaka T, Takaishi Y. 1995. Traditional medicine in Turkey. VII. Folk medicine in middle and west Black Sea regions. Econonomic Botany. 49:406- 422. 
Gouiric SC, Feresin G.E, Tapia AA, Rossomando PC, Schmeda-Hirschmann G, Bustos DA.

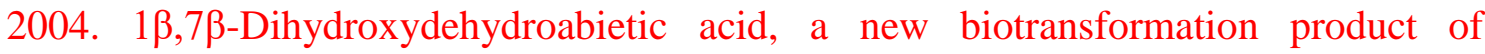
dehydroabietic acid by Aspergillus niger. World Journal of Microbiology \& Biotechnology 20: 281-284.

Kim HJ, Choi EH, Lee IS. 2004. Two lanostane triterpenoids from Abies koreana. Phytochemistry. 65:2545-2549.

Lee CK, Fang JM, Cheng YS.1995. Norditerpenes from Juniperus chinensis. Phytochemistry. 39:391-394.

Matsumoto T, Imai S, Sunaoko Y, Yoshinari T. 1988. The conversion of (+)-dehydroabietic acid into steroidal. Bull Chem Soc Jpn.61:723-727.

Miguel Del Corral JM, Gordaliza M, Salinero MA, San Feliciano A. 1994. ${ }^{13}$ C-NMR data for abieta-8,11,13-triene diterpenoids. Magn Reson Chem. 32:774-781.

Nayak SS, Ghosh AK, Srikanth K, Debnath B, Jha T. 2003. Antitussive activity of Abies webbiana Lindl. leaf extract against sulphur dioxide-induced cough reflex in mice. Phytother Res. 17:930- 932.

Nayak SS, Ghosh AK, Debnath B, Vishnoi SP, Jha T. 2004. Synergistic effect of methanol extract of Abies webbiana leaves on sleeping time induced by standard sedatives in mice and anti-inflammatory activity of extracts in rats. J Ethnopharmacol. 93:397-402.

Ohtsu H, Tanaka R, In Y, Matsunaga S, Tokuda H, Nishino H. 2000. New abietane diterpenoids from the cones of Larix kaempferi. Can J Chem. 78:31-40.

Prinz S, Mullner U, Heilimann J, Winkelmann K, Sticher O, Haslinger E, Hufner A. 2002. Oxidation products of abieticsacid and its methyl ester. J Nat Prod. 65:1530-1534

Singh RK, Bhattacharya SK, Acharya SB. 2000. Pharmacological activity of Abies pindrow. J Ethnopharmacol.73:47- 51.

Tanaka R, Ohtsu H, Matsunaga S. 1997. Abietane diterpene acids and other constituents from the leaves of Larix kaempferi. Phytochemistry. 46:1051-1057.

Toyang NJ, Ateh EN, Keiser J, Vargas M, Bach H, Tane P, Sondengam LB, Davis H. 2012. Toxicity, antimicrobial and anthelmintic activities of Vernonia guineensis Benth. (Asteraceae) crude extracts. J Ethnopharmacol.144: 700-704.

Vishnoi SP, Ghosh AK, Debnath B, Samanta S, Gayen S, Jha T. 2007. Antibacterial activity of Abies webianna. Fitoterapia.78:153- 155.

Xian-Wen Y, Lin F, Su-Mei L, Xiao-Hua L, Yong-Li L, Liang W, Yun-Heng S, Jun-Mian T, Xi Z, Xin-Ru L, Ning W, Yonghong L, Wei-Dong Z. 2010. Isolation, structure and 
bioactivities of abiesadines A-Y, 25 new diterpenes from Abies georgei Orr. Bioorg. Med Chem.18:744 754.

Yang XW, Li SM, Feng L, Shen YH, Tian JM, Liu XH, Zeng HW, Zhang C, Zhang WD. 2008. Abies anordines A-N: fourteen new norditerpenes from Abies georgei. Tetrahedron. 64:4354-4362

Zheng WJ, Fu LG. 1978. Flora Reipublicae Popularis Sinicae K, Ed. Z. Y. Wu. Science Press, Beijing, 55. 